\title{
Noviembre 2011
}

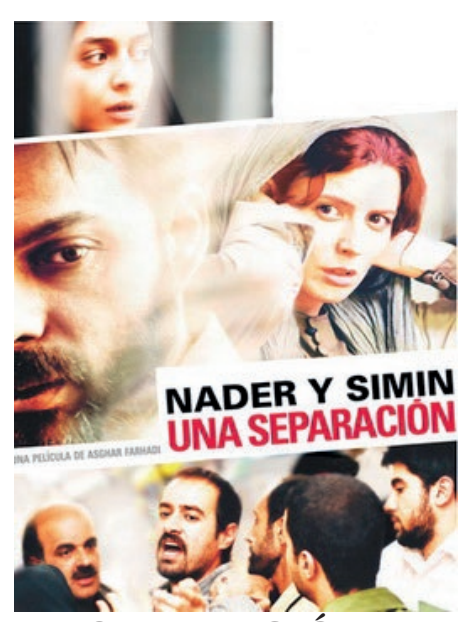

NADER Y SIMIN: UNA SEPARACIÓN DE ASGHAR FARHADI

La búsqueda de la verdad, una verdad que se oculta, que ocultan sus personajes por las razones que sean, esta idea inmanente se viene a desarrollar dentro de la trama, es decir conducir al espectador al desvelamiento de la verdad, aunque siempre surgen dudas, al tiempo mediante esa escenificación casi teatral, en interiores, siempre verosímil, vamos descubriendo el carácter de los personajes -al igual que su anterior trabajo A propósito de Elly- y la lógica que no deja paso al azar; todos mienten, pero todos dicen la verdad, algo ocultan, algo se nos escapa, un matiz, constituyéndose en definitiva metáfora de las propias contradicciones de una sociedad, siempre desde una posición de narrador omnisciente. 


\section{CRÍTICAS DE CINE / FILM REVIEWS}

Octubre-Diciembre, 2011

El drama parte de una situación en calma, de una situación cotidiana, un problema o conflicto generado que percute sobre el desarrollo de los acontecimientos trazando un retrato coral de un país. En este caso no se trata de ahondar en la problemática moral del divorcio, aunque la cinta comience y finalice con los protagonistas ante el juez, sino que este hecho constituye una especie de espoleta que activará todo un mecanismo dramático, a modo de thriller, sin abandonar una serie de temas que circulan una y otra vez por nuestras retinas, la responsabilidad, las consecuencias de nuestros actos, la moral religiosa como condicionante, el machismo y el papel de la mujer, las diferencias sociales, la mirada infantil inocente ante el drama.

Oso de oro Festival de Berlín de 2011

Oso de plata Festival de Berlín de 2011, mejor actor, todo el elenco masculino; Peyman Moadi, Shahab Hosseini y Babak Karimi

Oso de plata Festival de Berlín de 2011, mejor actriz, todo el elenco femenino; Sarina Farhadi y Sareh Bayat

\section{Ficha Técnica}

Película: Nader y Simin, una separación.

Título original: Jodaeiye Nader az Simin.

Dirección y guion: Asghar Farhadi.

País: Irán.

Año: 2011.

Interpretación: Peyman Moaadi (Nader), Leila Hatami (Simin), Sareh Bayat (Razieh), Shahab Hosseini (Hodjat), Sarina Farhadi (Termeh).

Producción: Asghar Farhadi.

Música: Sattar Oraki.

Fotografía: Mahmuoud Kalari.

Montaje: Hayedeh Safiyari.

Diseño de producción: Keyvan Moghaddam. 